\section{References}

Taagepera, Rein. 1991. "Building Democracy in Estonia." PS 24: 478-81.

Taagepera, Rein. 1993. Estonia: Return to Independence. Boulder: Westview.

\section{About the Author}

\section{Rein Taagepera}

Rein Taagepera is Professor of Social Science at the University of California, Irvine, and Dean of the School of Social Sciences at Tartu University, Estonia. He is coauthor of Seats and Votes: The Effects and Determinants of Electoral Systems (1989).

Cartoon by Ants Kasesalu, reproduced in Tallinn City Paper, Autumn 1992.

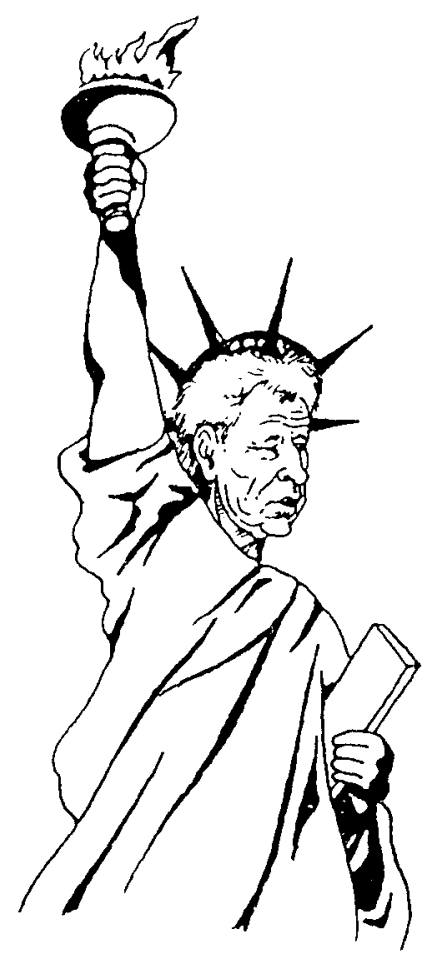

\title{
CDC Volunteers Helping to Build Democracies
}

\author{
Matthew Wagner, Citizens Democracy Corps, Inc.
}

The Moscow Human Rights Center is an umbrella organization for 15 human rights organizations and the first attempt in Russia to coordinate the activities of a wide range of human rights groups. Because the Center is breaking new ground, it needs guidance in strengthening its management practices, expanding its membership and fundraising activities, and maintaining liaisons with international human rights organizations. Because the Citizens Democracy Corps (CDC) is providing assistance in these and other areas of democratic institution building in Central Europe and the former Soviet Union, the Center looked to CDC for help.

CDC responded by enlisting the aid of Leon Leiberg, a Senior Fellow at the Institute for Advanced Studies in Justice at the American University in Washington, DC, who helped the Moscow Human Rights Center to tackle these challenges. Leiberg travelled to Moscow in late January as a volunteer in CDC's Citizens Volunteer Program and to discuss human rights from a western perspective and to advise the Center on its development issues.

This is just one of the many requests for assistance that the $\mathrm{CDC}$ is receiving from the countries of Central and Eastern Europe and the former Soviet Union. One way CDC is answering these requests is through its Citizens Volunteer Program, and the practical, on-site assistance it provides.

The Citizens Volunteer Program enlists the time and expertise of U.S. volunteers with experience in municipal administration, nonprofit management or university governance, and links them with their counterparts in the region to help them build private and public democratic institutions. These volunteer advisors work directly with local governments, nonprofit organizations and institutions of higher education for a minimum of two months, sharing their skills with the host institutions and helping them to strengthen regional and local governments.

The program covers almost all of the costs associated with these assignments. Host institutions provide housing, local transportation and translation services for volunteers, and $\mathrm{CDC}$ covers the cost of airfare. The main contribution volunteers make is their willingness to help and the experience they bring to the program.

The program's success in helping these institutions is particularly gratifying to CDC Executive Director Sol Polansky, a former U.S. Ambassador to Bulgaria. "What is most exciting to an old Cold War diplomat like myself is that reformers throughout the region look to this country for examples of how a civil society can work, and they look to CDC for assistance in making it work for them," Polansky said.

A number of volunteers have returned from assignments in the 
Citizens Volunteer Program, including:

- Derek Bok, President Emeritus of Harvard University, who has made two trips to Hungary to assess its higher education system, and who recently advised the Hungarian Par- liament on aspects of its higher education reform legislation.

- Harvey Sloane, former mayor of Louisville, Kentucky, who helped the mayor of Bucharest, Romania, to assess how he could better direct municipal services.
- Doug Fair, a consultant for nonprofit organizations, who helped the School for International Management and Business Administration in Sofia, Bulgaria, improve its management practices.

\title{
The Premature Senility of the New Democracies: The Hungarian Experience
}

\author{
Attila Ágh, University of Economic Sciences
}

Since the 1989 "revolutions," the democratizations in the East Central European countries (Poland, Czechoslovakia, and Hungary) have shown premature signs of aging. A short survey of contradictions could explain this "medical report."

\section{The Heterogeneity of Regions}

During the Cold War, Eastern Europe was thought of homogeneously united by a shared "totalitarian"' system. Since the 1989 revolutions, this false unit has divided into three markedly different parts: East-Central Europe (ECE), South Eastern Europe (SEE), and Eastern Europe proper (EE), the western republics of the former Soviet Union. These three subregions differ now more than ever in their history. It is the awkward Western strategy of crisis management that tries to handle them as a more or less homogeneous region with identical problems.

\section{Three Regions-Three Stages}

Using Rostow's model of systemic change, Eastern Europe (SEE and $E E)$ is in the stage of the initial or pretransition crisis; they have not reached the point of no return in systemic change. Indeed, some countries like Serbia or Romania show a newly emerging model of national communism. The ECE countries are in the second stage, in the genuine democratic transition, a "creative chaos" combining the features of both old and new systems. The present transition period is the most difficult, so the coming three to five years will be decisive for the fate of the Central European democratizations. Finally, the Southern European countries (Spain, Portugal, and Greece) have arrived at the third stage, the consolidation period.

\section{No Great Leap- No Return to the Past}

There are two theoretical as well as practical blind alleys in systemic change. The euphoria of the 1989 revolutions held promise of a quick and easy transition, a Great Leap Forward from East European misery to West European paradise. Disappointments over later developments have provoked the opposite extremist concept, a Great Leap Back-Return to the Past model. This explanation links the contradictions of the systemic change with a complete return to the situations after World War I and II. Both of the views and the political strategies they give rise to are simplistic and counterproductive.

The perspectives of politicians and political scientists are themselves in the stage of "initial crisis." They have not broken through to understanding the new condition, which is neither a copy of the West, nor the revival of the past. Now, there is also a new variant of the Great Leap Back model: the Third World model which simply adds all former socialist countries to the list of the developing countries without any regional specifications.

\section{Cycles of \\ ( $\mathbf{R e}-$ )Democratizations}

The best heuristic model for the Age of State Socialism is the theory of long waves with its half a century long Kondratieff cycle beginning after World War II and ending with the 1989 revolutions. According to this global framework, the last fifty years until 1989 brought a long period of easternization or deEuropeanization for ECE. ECE had its short cycles as well. These tenyear cycles were reform cycles, in which ECE countries tried to leave the political structure forced upon them by the Yalta system. These short cycles of reform began with smaller reforms in the workings of the given regime of state socialism but were extended more and more, from economic to social reforms. When they reached the sphere of politics and threatened the distribution of political power, conservative forces inside and outside reacted with counter-attack, the so-called normalizations or conservative rearrangements. Consequently in the ECE countries there were a series of eruptions of popular discontent (1956, 1968, 1981). These "revolutions", expressed contradictions between some socioeconomic liberalizations and the missing genuine democratizations. In the 1989 revolutions these 